\title{
EVALUATION OF TOTAL PHENOLS, TOTAL FLAVONOIDS, ANTIOXIDANT, AND ANTICANCER ACTIVITY OF MUCUNA PRURIENS SEED EXTRACT
}

\author{
KAVITHA K* \\ Department of Zoology, Ethiraj College for Women, Chennai - 600 008, Tamil Nadu, India. Email: kavikk4691@gmail.com \\ Received: 09 October 2017, Revised and Accepted: 07 December 2017
}

\section{ABSTRACT}

Objective: In recent years, herbal plants have been got more attention due to their diverse presence of phytochemicals and its biological properties. Hepatocellular carcinoma is one of the major worldwide problems primarily caused by hepatitis B and C virus infection. End-stage liver cancer treatment options are limited, thus requiring expensive liver transplantation which is not available in many countries.

Methods: In the present study, the Mucuna pruriens seed extract was analyzed for phytochemicals, antioxidant activity, total phenols, and total flavonoids content. The seed extract was further analyzed for its anticancer activity by culturing liver cancer cell line. The above protocols were done by standard methods.

Results: The seed extract of M. pruriens revealed more number of phytochemicals in different organic solvents. 1,1- Diphenyl- 2- picrylhydrozyl scavenging activity of plant extract was more in ethanol extract (98.051 \pm 0.547$)$ among all other solvents. The total phenols and flavonoids content in ethanol extract were $46.442 \pm 0.353 \mathrm{mg}$ gallic acid equivalent/g and $2.254 \pm 0.647 \mathrm{mg}-$ quercetin equivalent $/ \mathrm{g}$, respectively. IC ${ }_{50}$ value of $3-(4$, 5-dimethythiazol-2-yl)-2, 5-diphenyl tetrazolium bromide (MTT) analysis of Hep-2 cell line was $150(\mu \mathrm{g} / \mathrm{ml})$.

Conclusion: The present study revealed about the phytochemical contents and antioxidant potential of $M$. pruriens seeds. Further, the MTT analysis proved that the seed extract was effective against cancer cells and also used to treat many diseases.

Keywords: Mucuna pruriens, Antioxidant, Anticancer.

(C) 2018 The Authors. Published by Innovare Academic Sciences Pvt Ltd. This is an open access article under the CC BY license (http://creativecommons. org/licenses/by/4. 0/) DOI: http://dx.doi.org/10.22159/ajpcr.2018.v11i3.22999

\section{INTRODUCTION}

Cancer is an abnormal growth of cells that grow continually multiplying with the inability to be controlled or inhibited [1]. Cancer has been a constant conflict globally with a lot of development in treatment and preventative remedies. According to Chavan et al. [2], the number of people diagnosed with cancer is estimated globally about 11 million people; the victim number will rise to 16 million by 2020. Liver diseases have become one of the major causes of morbidity and mortality in human and animals all over globe and hepatotoxicity due to drugs appear to be the most common contributing factor [3].

Reactive oxygen species are class of highly reactive molecules, resulting by the metabolism of oxygen. These free radicals occur in the body due to lack of antioxidants. Oxidative damage of biomolecules occurs by rapid production of free radicals will lead to degenerative disorders such as aging, diabetes, cancer, and neural disorders $[4,5]$.

Ayurveda, a traditional Indian medical practice using herbal plants drugs has been successful from ancient time [6]. Many medicinal plants contain a large amount of antioxidants such as polyphenols, Vitamin E, and Vitamin C. Natural antioxidants improve the antioxidant capacity of the plasma and reduce the risk of cancer and cardiovascular diseases [7]. There are many synthetic antioxidants available in the market, but they have many side effects [8]. Hence, there is a need for more potent and less toxic antioxidants. It has been found that medicinal plants having polyphenolic compounds such as flavonoids possess antioxidant activity [9]. Polyphenolic compounds such as flavonoids, curcumin, tannins, alkaloid [10], resveratrol, gallocatechins [11], and xanthones [12] are all considered being anticancer compounds. Polyphenols have antioxidant properties which are due to their high reactivity as a hydrogen donor or electron donor which stabilize and delocalize the unpaired electron $[13,14]$.
Mucuna pruriens Linn. belongs to the family Fabaceae is the most popular drug in Ayurvedic system of medicine [15-18]. It is commonly known as velvet bean or cowitch or cowhage or Alkushi [19]. All the parts of M. pruriens plant possess medicinal value. Seeds of the plants have antidiabetics activity [20], antimicrobial activity [21], and antivenom activity [22]. The phytochemicals present in the seeds of the M. pruriens increase the fertility in men [23]. Levodopa synthesis from seeds regulates central nervous system and also used to treat Parkinson's diseases [24-27].

\section{METHODS}

\section{Collection and process of plant sample}

The seeds of $M$. pruriens were collected from Namakkal district, Tamil Nadu, during the month of October-November and authenticated by Dr. P. Jayaraman, Botanist, Plant Anatomy Research Centre, Chennai-45. The specimen number is PARC/2015/2214.

The seeds were air-dried and powered using ball mill machine. The powered sample was weighed and preserved in the closely tight clean jar before the extraction.

\section{Preparation of plant extraction}

Plant extracts were prepared by standard methods [28,29]. About $5 \mathrm{~g}$ of dried seed fine powder of $M$. pruriens was extracted with $20 \mathrm{ml}$ water, ethanol, acetone, chloroform, and petroleum ether for 1 min using ultra Turrax Mixer (13,000 rpm) and soaked overnight at room temperature. The sample was then filtered through Whatman No 1 filter paper in Buchner funnel. The filtered solution was evaporated under vacuum in a Rotaevator at $40^{\circ} \mathrm{C}$ to a constant weight and then dissolved in the respective solvent. The concentrated extracts were stored in airtight container in the refrigerator below $10^{\circ} \mathrm{C}$. 
The preliminary analysis of phytochemicals screening was done by standard methods [30,31].

\section{Estimation of total phenolic content}

The total phenol content in seed extract of M. pruriens was determined by standard method [32]. $100 \mu \mathrm{l}$ of ethanol extract was mixed with $0.5 \mathrm{ml}$ of Folin-Ciocalteau reagent (1/10 dilution) and $1.5 \mathrm{ml}$ of sodium carbonate $(2 \% \mathrm{w} / \mathrm{v})$. The blends were incubated in the dark at room temperature for $15 \mathrm{~min}$. The absorbance of blue-colored solution of sample was measured at $765 \mathrm{~nm}$ using ultraviolet (UV)spectrophotometer. Gallic acid used to make standard curve. Total phenolic contents were expressed as mg of gallic acid equivalent (GAE) per gram dry weight of plant powder.

\section{Estimation of total flavonoids content}

Total flavonoid content in seed extract of M. pruriens was determined by aluminum chloride colorimetric method [33]. $0.5 \mathrm{ml}$ of seed extract of $M$. pruriens and the volume was made up to $3 \mathrm{ml}$ by adding methanol. Then, $0.1 \mathrm{ml}$ of $10 \%$ aluminum chloride (10\%), $0.1 \mathrm{ml}$ of $1 \mathrm{M}$ potassium acetate, and $2.8 \mathrm{ml}$ of distilled water were added sequentially. After incubation at room temperature for $30 \mathrm{~min}$, the absorbance of the reaction mixture was measured at $415 \mathrm{~nm}$ with a spectrophotometer. A standard generated using known concentration of quercetin. The amount of $10 \%$ aluminum chloride was substituted by the same amount of distilled water in blank.

\section{1,1- Diphenyl- 2- picrylhydrozyl (DPPH) scavenging activity of M. pruriens seeds}

Qualitative assay of antioxidant activity

Antioxidant assay of $M$. pruriens was estimated for its free radical scavenging activity using DPPH free radicals.

\section{Principle}

DPPH is a stable free radical with purple color (absorbed at $517 \mathrm{~nm}$ ). If free radicals have been scavenged, DPPH will degenerate to yellow color. The character of this assay shows free radicla scavenging activity.

\section{Screening method}

Qualitative analysis of antioxidant potential of $M$. pruriens seed was determined by standard method [34]. $50 \mu$ l of seed extracts of $M$. pruriens were taken in five separate wells of microtiter plate. 100 $\mu \mathrm{l}$ of $0.1 \%$ methanolic DPPH was added to the different samples and incubated for $30 \mathrm{~min}$ in dark condition. The samples were then taken, observed for discoloration from purple to yellow or pale pink which were considered as strong and weak positive response of free scavenging activity, respectively. The antioxidant-positive samples were subjected for further quantitative analysis.

\section{Quantitative assay of antioxidant activity}

$100 \mu \mathrm{l}$ of different extracts of seed samples were mixed with $2.7 \mathrm{ml}$ of methanol and incubated for $30 \mathrm{~min}$ in dark condition. Subsequently, at every 5 min interval, the absorption maxima of the solution were measured using UV double-beam spectra scan (Chemito, India) at $517 \mathrm{~nm}$. The antioxidant activity of the sample was compared with known synthetic standard of $0.16 \%$ of butylated hydroxytoluene [35]

\section{In vitro anticancer activity}

Cell line and culture

Hep-2 (liver) cell lines were obtained from National Center for Cell Sciences, Pune. The cells were maintained in minimal essential media supplemented with $10 \%$ fetal bovine serum (FBS), penicillin (100 U/ $\mathrm{ml})$, and streptomycin $(100 \mu \mathrm{g} / \mathrm{ml})$ in a humidified atmosphere of 50 $\mu \mathrm{g} / \mathrm{ml} \mathrm{CO}_{2}$ at $37^{\circ} \mathrm{C}$.

\section{Reagents}

Minimum essential medium was purchased from Hi-Media Laboratories, FBS was purchased from Cistron laboratories, and trypsin, methylthiazolyl diphenyl-tetrazolium bromide (MTT), and dimethyl sulfoxide (DMSO) were purchased from (Sisco research laboratory chemicals Mumbai). All of other chemicals and reagents were obtained from Sigma-Aldrich, Mumbai.

\section{Principle of assay}

This is a colorimetric assay that measures the reduction of yellow MTT by mitochondrial succinate dehydrogenase. The MTT enters the cells and passes into the mitochondria where it is reduced to an insoluble, colored (dark purple) formazan product. The cells are then solubilized with an organic solvent (e.g., isopropanol) and the released, solubilized formazan reagent is measured spectrophotometrically. Since reduction of MTT can only occur in metabolically active cells, the level of activity is a measure of the viability of the cells.

\section{In vitro assay for cytotoxicity activity (MTT assay)}

The cytotoxicity of sample (Mucuna seed extract) on Hep-2 (liver) cell line was determined by the MTT assay [36]. Cells $\left(1 \times 10^{5} /\right.$ well $)$ were plated in $1 \mathrm{ml}$ of medium/well in 24-well plates (Costar Corning, Rochester, NY). After $24 \mathrm{~h}$ incubation, the cell reaches the confluence. Then, cells were incubated in the presence of various concentrations of the samples in $0.1 \%$ DMSO for $24 \mathrm{~h}$ at $37^{\circ} \mathrm{C}$. After removal of the sample solution and washing with phosphate-buffered saline ( $\mathrm{pH} 7.4)$, $200 \mu \mathrm{l} /$ well $(5 \mathrm{mg} / \mathrm{ml})$ of $0.5 \%$ MTT phosphate-buffered saline solution was added. After $4 \mathrm{~h}$ incubation, $0.04 \mathrm{M} \mathrm{HCl} /$ isopropanol was added. Viable cells were determined by the absorbance at $570 \mathrm{~nm}$. Measurements were performed and the concentration required for a $50 \%$ inhibition of viability (IC $\mathrm{C}_{50}$ ) was determined graphically. The absorbance at $570 \mathrm{~nm}$ was measured with a UV-spectrophotometer using wells without sample containing cells as blanks. The effect of the samples on the proliferation of Hep-2 (liver cancer cell line) was expressed as the $\%$ cell viability, using the following formula:

Table 1: Preliminary phytochemical analysis of $M$. pruriens seed extracts

\begin{tabular}{|c|c|c|c|c|c|}
\hline Phytochemicals & Aqueous & Ethanol & Acetone & Chloroform & Petroleum Ether \\
\hline Tannin & ++ & +++ & - & - & - \\
\hline Saponin & ++ & +++ & - & - & - \\
\hline Flavonoids & ++ & ++ & + & - & - \\
\hline Quinones & + & + & + & - & - \\
\hline Glycosides & - & - & - & - & - \\
\hline Cardio glycosides & - & - & - & - & - \\
\hline Terpenoids & + & + & + & - & - \\
\hline Coumarin & + & ++ & + & - & - \\
\hline Steroids & + & + & + & - & - \\
\hline Alkaloids & + & ++ & + & - & - \\
\hline Anthocyanin & - & - & - & - & - \\
\hline B-cyanin & + & + & - & - & - \\
\hline
\end{tabular}

++: High amount, +: Present, -: Absent 
$\%$ cell viability=Absorbance of treated cells/A570 of control cells $\times 100 \%$

\section{RESULTS AND DISCUSSIONS}

Many plants display their characters for anticancer, anti-inflammatory, antibacterial, and anti-allergic nature [37] and could be useful in therapeutic roles [38,39]. The phytochemical constituents of M. pruriens seeds were shown in Fig. 1 and Table 1. Ethanol extract of $M$. pruriens revealed more phytocontents than other extracts.

Tannins have general antimicrobial and antioxidant activities [40]. Current reports show that tannins may have potential value such as cytotoxic and antineoplastic agent [41]. Saponins have antifungal properties [42,43]. Saponins are used in hypercholesterolemia, hyperglycemia, antioxidant, anticancer, anti-inflammatory, and weight loss $[44,45]$. Alkaloids tend to be organic and natural ingredients that have nitrogen and are also physiologically active together with sedative and analgesic roles. Several workers have reported the analgesic [46,47], antispasmodic, and antibacterial properties of alkaloids $[46,47]$. They also reduce stress and depression symptoms [48]. Steroids have been reported to have antibacterial properties [49], and they are very important compounds, especially due to their relationship with compounds such as sex hormones [50].

Qualification assay of M. pruriens seed results were shown in Fig. 2 and Table 2. The results revealed that the aqueous and ethanol extractions were shown highly positive responses. Quantitative free scavenging activity of $M$. pruriens seeds were shown in Table 3, which indicates that the ethanol extract was shown more percentage of free radical scavenging activity among other extractions.

Total phenols content and total flavonoids content of the ethanol extract of seed were shown in Table 4. Several studies have described the antioxidant potential of medicinal plants which are rich in phenolic compounds [51,52]. They also possess other biological properties such as antiaging, anti-apoptosis, anti-carcinogen, anti-atherosclerosis, anti-inflammation, cardiovascular protection, and improvement of endothelial function [53].

Flavonoids have been reported to exert a wide range of biological activities such as antioxidant, anti-inflammatory, antimicrobial, antiallergic $[9,54,55]$, cytotoxic anti-tumor, treatment of neurodegenerative diseases, and vasodilatory action [56-58]. In the present study, the significant amount of phenols and flavonoids were observed which might responsible for free radical scavenging activity.

The MTT assay is a rapid and highly accurate colorimetric approach that widely used to determine cell growth and cell cytotoxicity, particularly in the development of new drug. It measures cell membrane integrity by determining mitochondrial activity through enzymatic reaction on the reduction of MTT to formazan [59-61].

Since $\mathrm{IC}_{50}$ value for Hep-2 (liver) cell line $(150 \mu \mathrm{g} / \mathrm{ml})$ Mucuna seed extract was found to be effective, the reduction percentage of MTT at $24 \mathrm{~h}$ also estimated for Hep-2 (liver) cells (Fig. 3, Table 5 and Graph 1). When incubated with the extract, it induced cytotoxicity in a significant manner which implicits the damage to the member integrity of the cell when contributed with control. The cytotoxicity was minimized in the extract-treated cells and near normal level was attained at various

Table 2: Qualitative free radical scavenging activity of M. pruriens

\begin{tabular}{ll}
\hline Plant samples & Response \\
\hline C=Control & - \\
S=BHT (Standard) & +++ \\
E=Ethanol & +++ \\
Aq=Aqueous & ++ \\
A=Acetone & \pm \\
C=Chloroform & - \\
P.E=Petroleum ether & - \\
\hline
\end{tabular}

+++: High amount, +: Present,t: Semi-positive, -: Absent. BHT: Butylated hydroxytoluene

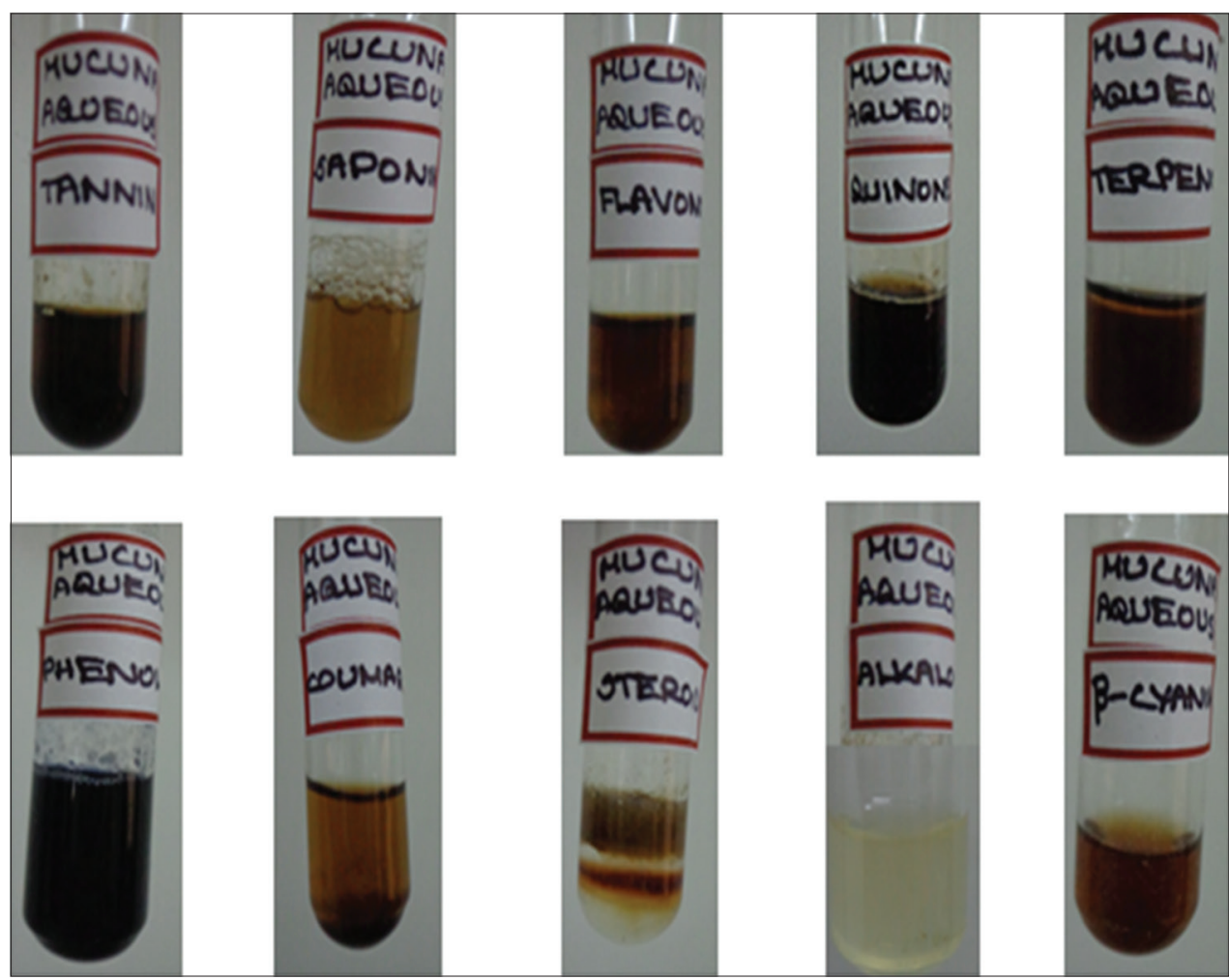

Fig. 1: Preliminary phytochemical analysis of ethanol extract of Mucuna pruriens seed extracts 
Table 3: DPPH free radical scavenging activity of $M$. pruriens seed extracts

\begin{tabular}{|c|c|c|c|c|c|c|c|}
\hline \multirow[t]{2}{*}{ Samples } & \multicolumn{7}{|l|}{ Time in minutes } \\
\hline & $\mathbf{0}$ & 5 & 10 & 15 & 20 & 25 & 30 \\
\hline Standard & $61.038 \pm 0.547$ & $90.909 \pm 0.547$ & $97.402 \pm 0.547$ & $98.051 \pm 0.547$ & $98.701 \pm 0.547$ & $98.701 \pm 0.547$ & $98.701 \pm 0.547$ \\
\hline Ethanol & $94.155 \pm 0.547$ & $96.753 \pm 0.547$ & $97.402 \pm 0.547$ & $97.402 \pm 0.547$ & $* 98.051 \pm 0.547$ & $* 98.051 \pm 0.547$ & $* 98.051 \pm 0.547$ \\
\hline Acetone & $70.129 \pm 0.547$ & $79.220 \pm 0.547$ & $81.168 \pm 0.547$ & $81.818 \pm 0.547$ & $82.467 \pm 0.547$ & $83.116 \pm 0.547$ & $83.766 \pm 0.547$ \\
\hline Petroleum ether & $* * 53.896 \pm 0.547$ & $56.441 \pm 0.547$ & $59.090 \pm 0.547$ & $59.740 \pm 0.547$ & $59.740 \pm 0.547$ & $59.740 \pm 0.547$ & $60.389 \pm 0.547$ \\
\hline Chloroform & $57.142 \pm 0.547$ & $59.090 \pm 0.547$ & $59.090 \pm 0.547$ & $59.740 \pm 0.547$ & $60.389 \pm 0.547$ & $60.389 \pm 0.547$ & $61.038 \pm 0.547$ \\
\hline
\end{tabular}

Each value is mean \pm SD value of 5 samples. Standard versus ethanol ${ }^{*} \mathrm{p}<0.001$, standard versus petroleum ${ }^{* *} \mathrm{p}>0.01 .{ }^{*} \mathrm{p}$ level of significance, ${ }^{* *} \mathrm{p}$ level of insignificance.

SD: Standard deviation, DPPH: 1,1- Diphenyl- 2- picrylhydrozyl

Table 4: Total phenols and total flavonoids content of ethanol extract of $M$. pruriens seeds

\begin{tabular}{ll}
\hline Content & M. pruriens \\
\hline $\begin{array}{l}\text { Total phenols content (mg GAE/g dry } \\
\text { sample) }\end{array}$ & $46.442 \pm 0.353 \mathrm{mg} / \mathrm{g}$ \\
$\begin{array}{l}\text { Total flavonoids content (mg QE/g dry } \\
\text { sample) }\end{array}$ & $2.254 \pm 0.647 \mathrm{mg} / \mathrm{g}$ \\
\hline
\end{tabular}

Each value is mean \pm SD value of 3 samples. GAE: Gallic acid equivalent, $Q E$ : Quercetin equivalent

Table 5: MTT reduction (\%) on Hep-2 cell line

\begin{tabular}{lll}
\hline Concentration $(\mu \mathrm{g} / \mathbf{m l})$ & $\begin{array}{l}\text { MTT } \\
\text { reduction (\%) }\end{array}$ & IC $_{50}$ \\
\hline Control & 98.17 & $150(\mu \mathrm{g} / \mathrm{mL})$ \\
50 & 87.25 & \\
100 & 79.14 & \\
150 & 49.63 & \\
200 & 23.08 & \\
Cyclophosphamide (Positive & 12.37 & \\
control) & & \\
\hline
\end{tabular}

MTT: 3-(4, 5-dimethythiazol-2-yl)-2, 5-diphenyl tetrazolium bromide

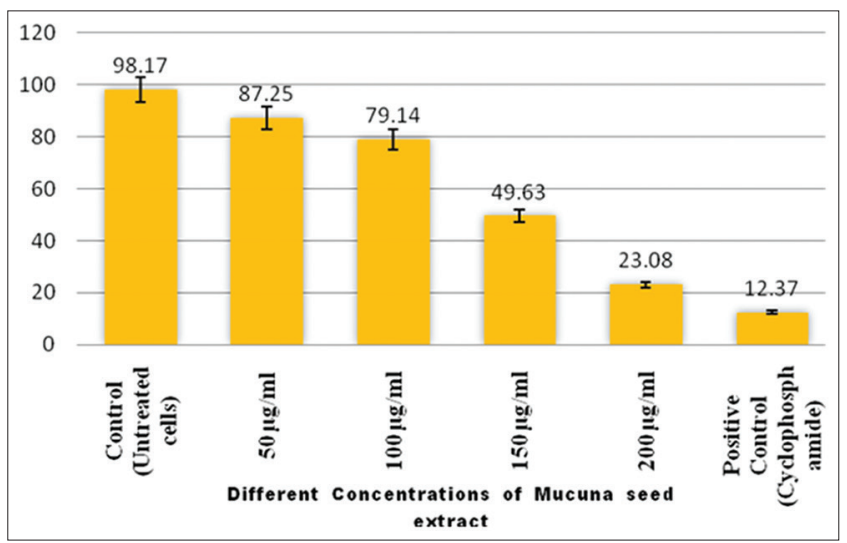

Graph 1: 3-(4, 5-dimethythiazol-2-yl)-2, 5-diphenyl tetrazolium bromide reduction (\%) on Hep-2 cell line

concentrations (50 $\mu \mathrm{g} / \mathrm{ml}, 100 \mu \mathrm{g} / \mathrm{ml}, 150 \mu \mathrm{g} / \mathrm{ml}$, and $200 \mu \mathrm{g} / \mathrm{ml}$ ), and maximum effect was found when treated at $150 \mu \mathrm{g} / \mathrm{ml}$. From the above results, it was confirmed that Mucuna seed extract at $150 \mu \mathrm{g} / \mathrm{ml}$ seems to offer significant protection and maintain the structural integrity of the hepatocellular membrane and this active concentration was followed for further studies.

\section{CONCLUSION}

It can be summarized that the plant selected for the present study having importance in traditional medicine can be considered as a source for

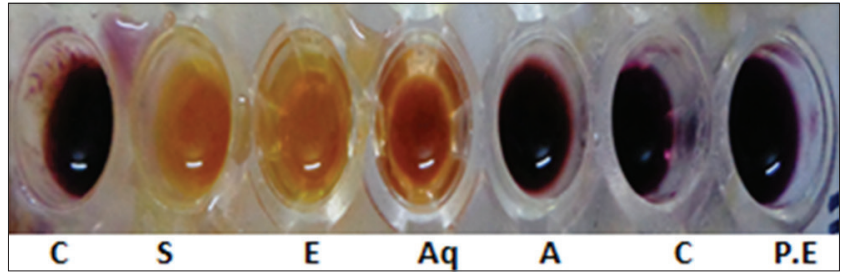

Fig. 2: Qualitative free radical scavenging activity of Mucuna pruriens seeds

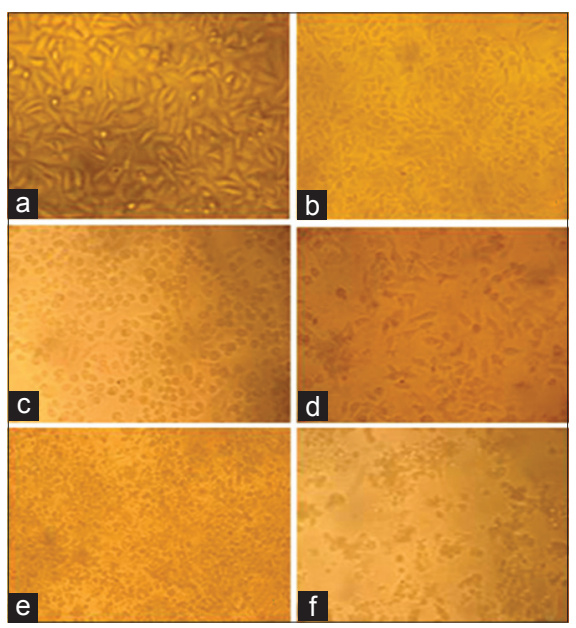

Fig. 3: 3-(4, 5-dimethythiazol-2-yl)-2, 5-diphenyl tetrazolium bromide reduction (\%) on Hep-2 cell line (a) control cells (untreated), b: Mucuna prurient seed extract $50 \mu \mathrm{g} / \mathrm{ml},(\mathrm{c})$

M. pruriens seed extract $100 \mu \mathrm{g} / \mathrm{ml}$ (d) M. pruriens seed extract $150 \mu \mathrm{g} / \mathrm{ml}$ (e) M. pruriens seed extract $200 \mu \mathrm{g} / \mathrm{ml}$ (f) cyclophosphamide (positive control) $80 \mu \mathrm{g} / \mathrm{ml}$

the isolation, identification, and development of novel and effective anticancer and antioxidant agents. Hence, the research data of the present findings may serve as a guideline for the standardization and validation of natural drugs containing the selected medicinal plants as ingredients.

\section{AUTHOR CONTRIBUTION}

Kavitha K: The research work was designed and carried out.

\section{CONFLICTS OF INTERESTS}

The author does not have any conflict of interest.

\section{REFERENCES}

1. Ochwang' ID, Kimwele CN, Oduma JA, Gathumbi PK, Mbaria JM, Kiama SG. Medicinal plants used in treatment and management of cancer in Kakamega County Kenya. J Ethnopharmacol 2014;151:1040-55.

2. Chavan SS, Damal EM, Prashant B, Shamkuwar PP, Pawar DP. Traditional medicinal plants for anticancer activity. Int J Curr Pharm 
Res 2013;5:50-4

3. Nadeem MP, Dandiya PC, Pasha M, Imran D, Balani K, Vohora SB. Hepatoprotective activity of Solanum nigrum fruits. Fitoterapia 1997;68:245-51.

4. Sas K, Robotka H, Toldi J, Vecsei L. Mitochondrial metabolic disturbances, oxidative stress and kynurenine system, with focus on neurodegenerative disorders. J Neurol Sci 2007;257:221-39.

5. Hyun DH, Hernandez JO, Mattson MP, de Cabo R. The plasma membrane redox system in aging. Ageing Res Rev 2006;5:209-20.

6. Balachandran P, Govindarajan R. Cancer - an ayurvedic perspective. Pharmacol Res 2005;51:19-30

7. Prior RL, Cao G. Antioxidant phytochemicals in fruits and vegetables. Diet and health implications. Hortic Sci 2000;35:588-92.

8. Ito N, Fukushima S, Hagiwara A, Shibata M, Ogiso T. Carcinogenicity of butylated hydroxyanisole in F344 rats. J Natl Cancer Inst 1983;70:343-52.

9. Cook NC, Samman S. Flavanoids: Chemistry, metabolism, cardio protective effects and dietary sources. Nutr Biochem 1996;7:66-76.

10. Davis L, Kuttan G. The effect of Withania somnifera on CTL activity. J Exp Clin Cancer Res 2002;21:115-8.

11. Azmi AS, Bhat SH, Hanif S, Hadi SM. Plant polyphenols mobilize endogenous copper in human peripheral lymphocytes leading to oxidative DNA breakage: A putative mechanism for anticancer properties. FEBS Lett 2006;580:533-8.

12. Hashim MN, Rahmani, M, Lian EG, Sukari MA, Yahayu M, Oktima, W, et al. Ant proliferative activity of xanthones isolated from Artocarpus obtusus. J Biom Biotechnol 2012;130627:1-9.

13. Rice-Evans C, Miller N, Paganga G. Antioxidant properties of phenolic compounds. Trends Plant Sci 1997;2:152-9.

14. Chopra RN, Nayar SL, Chopra IC. Glossary of Indian Medicinal Plants. New Delhi: CSIR; 1956.

15. Krishnaveni M. Antioxidant activity of selected plants. Int J Pharm Pharm Sci 2014;6:126-8.

16. Lorenzetti E, MacIsaac S, Arnason JT, Awang DV, Buckles D. The phytochemistry, toxicology and food potential of velvet bean (Mucuna adans spp., Fabaceae) cover crops of West Africa: Contributing to sustainable agriculture. Ibadan, Nigeria: IDRC, Ottawa, Canada \& IITA; 1998. p. 57.

17. Khare CP. Encyclopedia of Indian medicinal plants. Berlin Heidelberg: Springer Verley; 2004.

18. Mishra L, Wagner H. Lipid derivatives from Mucuna pruriens seeds. Indian J Chem 2006;45:801-4

19. Kavitha C, Thangamani C. Amazing bean "Mucuna pruriens": A comprehensive review. J Med Plants Res 2014;8:138-43.

20. Donati D, Lampariello LR, Pagani R, Guerranti R, Cinci G, Marinello E. Antidiabeticoligocyclitols in seeds of Mucuna pruriens. Phytother Res 2005;19:1057-60.

21. Rayavarapu AK, Kaladhar DS. Evaluation of antimicrobial activity of Mucuna pruriens on plant pathogens. Asian J Biochem Pharm Res 2011;2:593-600.

22. Tan NH, Fung SY, Sim SM, Marinello E, Guerranti R, Aguiyi JC, et al. The protective effect of Mucuna pruriens seeds against snake venom poisoning. J Ethnopharmacol 2009;123:356-8.

23. Shukla KK, Mahdi AA, Ahmad MK, Jaiswar SP, Shankwar SN, Tiwari SC, et al. Mucuna pruriens reduces stress and improves the quality of semen in infertile men. Evid Based Complement Alternat Med 2010;7:137-44

24. Hussian G, Manyam BV. Mucuna pruriens proves more effective than L DOPA in Parkinsons' disease animal model. Phytother Res 1997;11:419-23.

25. Nagashayana N, Sankarankutty P, Nampoothiri MR, Mohan PK, Mohan KK. Association of L-DOPA with recovery following Ayurveda medication in Parkinson's disease. J Neurol Sci 2000;176:124-7.

26. Katzenschlager R, Evans A, Manson A, Patsalos PN, Ratnaraj N, Watt H, et al. Mucuna pruriens in Parkinson's disease: A double blind clinical and pharmacological study. J Neurol Neurosurg Psychiatry 2004:75:1672-7.

27. Ovallath S, Deepa P. The history of Parkinsonism: Descriptions in ancient Indian medical literature. Mov Disord 2013;28:566-8.

28. Pizzale L, Bortolomeazzi R, Vichi S, Conte LS. Antioxidant activity of sage and oregano extracts related to their phenolic compound content. J Sci Food Agric 2002;82:1645-51.

29. Lu Y, Foo Y. Antioxidant activities of polyphenols from sage (Salvia officinalis). Food Chem 2001;75:197-202.

30. Siddiqui AA, Ali M. Practical Pharmaceutical Chemistry. I $^{\text {st }}$ ed. New Delhi, India: CBS Publishers and Distributors; 1997. p. 126-31.

31. Savithramma N, Rao ML, Ankanna S. Screening of traditional medicinal plants for secondary metabolites. Int J Res Pharm Sci 2011;2:643-7.
32. Lister E, Wilson P. Measurement of Total Phenolics and ABTS Assay for Antioxidant Activity (Personal Communication). Lincoln, New Zealand: Crop Research Institute; 2001

33. Madaan R, Bansal G, Kumar S, Sharma A. Estimation of total phenols and flavonoids in extracts of Actaea spicata roots and antioxidant activity studies. Indian J Pharm Sci 2011;73:666-9.

34. George $\mathrm{H}$, Teng $\mathrm{CM}$, Wu CL, Ko FN. Marchantin has a natural antioxidant and free radical scavenger. Arch Biochem Biophys 1996;334:18-26.

35. Lee SE, Hwang HJ, Ha JS, Jeong HS, Kim JH. Screening of medicinal plant extracts for antioxidant activity. Life Sci 2003;73:167-79.

36. Mosmann T. Rapid colorimetric assay for cellular growth and survival: Application to proliferation and cytotoxicity assays. J Immunol Methods 1983;65:55-63.

37. Ekam VS, Ebong PE. Serum protein and enzymes levels in rats following administration of antioxidant vitamins during caffeinated and non-caffeinated paracetamol induced hepatotoxicity Nigeria. J Physiol Sci 2007;22:65-8

38. Jisika M, Ohigashi H, Nogaka H, Tada T, Hirota M. Bitter steroid glycosides, Vernon sides A1, A2, and A3 and related B1 from the possible medicinal plant Vernonia amygdalina used by wild Chimpanzees. Tetrahedron 1992;48:625-30.

39. Obochi GO. Effect of Alcohol - Kolanut Interaction on Biochemical Indices of Neuronal Function and Gene Expression in Wistar Albino Rats. A PhD Thesis Submitted to the Graduate School, University of Calabar Nigeria; 2006

40. Rivière C, Hong VN, Pieters L, Dejaegher B, Heyden YV, Van MC, et al. Polyphenols isolated from antiradical extracts of Mallotus metcalfianus. Phytochemistry 2009;70:86-94

41. Aguinaldo AM, El-Espeso, Guovara BQ, Nano MG. Phytochemistry. In: Guevara BQ, editor. A Guide Book to Plant Screening Phytochemical and Biological. Manila, Philippines: University of Santo Tomas; 2005.

42. Aboada OO, Efuwape BM. Antibacterial properties of some Nigerian species. Biol Res Comm 2001;13:183-8.

43. Mohanta TK, Patra JK, Rath SK, Pal DK, Thatoi HN. Evaluation of antimicrobial activity and phytochemical screening of oils and nuts of Semicarpus anacardium (L). Sci Res Essay 2007;2:486-90.

44. Mandal P, Sinha Babu SP, Mandal NC. Antimicrobial activity of saponins from Acacia auriculiformis. Fitoterapia 2005;76:462-5.

45. Manjunatha BK. Antibacterial activity of Pterocarpus antalinus. Ind J Pharm Sci 2006;68:115-6.

46. Antherden LM. Textbook of Pharmaceutical Chemistry. $8^{\text {th }}$ ed. London: Oxford University Press; 1969. p. 813-4.

47. Basha SF, Muthukumar C. Preliminary phytochemical screening and in vitro angiotensin activity of bioactive compound - Steroid isolated from Sargassum ilicifolium. Int J Pharm Pharm Sci 2014;6:299-301.

48. Stray F. The Natural Guide to Medicinal herbs and Plants. London: Tiger Books International; 1998. p. 12-16.

49. Okwu DE, Okwu ME. Chemical composition of Spondias mombin Linn. Plant Parts J Sustain Agric Environ 2004;6:140-7.

50. Madhu M, Sailaja V, Satyadev TN, Satyanarayana MV. Quantitative phytochemical analysis of selected medicinal plant species by using various organic solvents. J Pharm Phytochem 2016;5:25-9.

51. Raquel FE. Bacterial lipid composition and antimicrobial efficacy of cationic steroid coppounds. Biochem Biophys Acta 2007;1768:2500-9.

52. Okwu DE. Evaluation of chemical composition of medicinal plants belonging to Euphorbiaceae. Pak Vet J 2001;14:60-162.

53. Brown JE, Rice-Evans CA. Luteolin-rich artichoke extract protects low density lipoprotein from oxidation in vitro. Free Radic Res 1998;29:247-55

54. Krings U, Berger RG. Antioxidant activity of roasted foods. Food Chem 2001;72:223-9.

55. Han X, Shen T, Lou H. Dietry polyphenols and their biological significance. Int J Mol Sci 2007;12:950-988

56. Murray MT. Quercetinnature's antihistamine. Better Nutr 1998;60:10.

57. Cushnie TP, Lamb AJ. Antimicrobial activity of flavonoids. Int J Antimicrob Agents 2005;26:343-56.

58. Williams RJ, Spencer JP, Rice-Evans C. Serial review: Flavonoids and is of lavonones (phytoestrogens): Absorption, metabolism and bioactivity. Free Radic Biol Med 2004;36:838-49.

59. Tsuchiya H. Structure-dependent membrane interaction of flavonoids associated with their bioactivity. Food Chem 2010;120:1089-96.

60. Chebil L, Humeau C, Falcimagine A, Engasser J, Ghoul M. Enzymatic acylation of flavonoids. Process Biochem 2006;41:2237-51.

61. Dab R, Ragavan B. Studies on phytochemicals, antioxidant and cytotoxicity effect of Hybanthus enneaspermus. Int J Pharm Pharm Sci 2014;6:567-72. 